\title{
Smoking, HIV infection, and gay men in the United States
}

\author{
David R Arday, Brian R Edlin, Gary A Giovino, David E Nelson
}

Office on Smoking and Health, National Center for Chronic Disease Prevention and Health Promotion (K-50), Centers for Disease Control and Prevention, 4770 Buford Hwy, NE, Atlanta, GA 30341. 3724, USA

D R Arday

G A Giovino

D E Nelson

Division of HIV/AIDS, National Center for Infectious Diseases (E-45), Centers for Disease Control and Prevention, 1600 Clifton Rd., Atlanta, GA 30333, USA B R Edlin

Correspondence to D A Arday. Dr Arday is with the Epidemic Intelligence Service.
On 13 August 1992, the Wall Street fournal announced, "The tobacco industry, after being beaten back in its controversial efforts to woo blacks and women, may be turning its marketing muscle on another minority: homosexuals". ${ }^{1}$ Philip Morris Inc reportedly planned to unveil its new Benson \& Hedges Special Kings brand using advertisements in the national gay press.

Homosexual men in the US have been devastated by the epidemic of human immunodeficiency virus (HIV) infection. Niche marketing of tobacco products to homosexuals may be particularly invidious if smoking enhances the morbidity or mortality of HIV infection. Three questions bear on this possibility: Is cigarette smoking more prevalent among homosexual men than it is among heterosexual men? Does smoking increase the risk of acquiring HIV infection? Does smoking enhance the progression of HIV disease? Unfortunately, little conclusive research has been reported in any of these areas.

\section{Smoking prevalance among gay men}

Although the prevalence of smoking has declined in recent years, ${ }^{2}$ data from several sources suggest that the prevalence of smoking among gay men is at least as great and probably somewhat greater than among men in the total population. Among a cohort of 202 Washington, DC, and New York City homosexual men (mean age: 34 years) enrolled in a prospective study of risk factors for HIV

13 or more years of education), $37.3 \%$ (155) reported they were current cigarette smokers (J Kelly, EMT Associates, Sacremento, CA, unpublished report, 1991). By comparison, the 1990 NHIS smoking prevalence among all US men over the age of 18 was $28.4 \%$, and among all US white men over the age of 25 with 13 to 15 years of education it was $25.4 \%{ }^{2}$ The 1989 smoking prevalence among all men over the age of 18 in San Francisco was $25.5 \%$, according to a study by the State of California. ${ }^{5}$

\section{Smoking and the risk of HIV infection}

Whether smoking affects the risk of acquiring HIV infection is uncertain. Several research teams ${ }^{3,4,6}$ have reported a higher risk of sexually acquired HIV infection among cigarette smokers, but these studies have been limited in their ability to control for the behaviour most likely to be the strongest risk factor for HIV acquisition - unprotected sexual intercourse with an infected partner. Smoking was clearly associated with riskier sexual practices in all these studies. In one study of Haitian women, ${ }^{6}$ however, the association between smoking and HIV infection among a sub-group of women living in houses with concrete floors (a marker for higher socioeconomic status) remained after the data were adjusted for the number of sexual partners.

\section{Smoking and immune function}

Numerous clinical studies have shown alterimmune deficienc syndrome (AIDS), $46 \%$ (93) reported they were active cigarette smokers at enrollment in $1982 .^{3}$ By comparison, National Health Interview Survey (NHIS) data showed that $35.1 \%$ of US adult men over the age of 18 smoked in $1983 .^{2}$

In the 1984 population-based San Francisco Men's Health Study (998 men aged 24-55 years) the smoking prevalence was $41.8 \%$ among homosexual/bisexual enrollees, compared with $27.9 \%$ among heterosexual enrollees. ${ }^{4}$ The prevalence of heavy smoking $(\geqslant 2$ packs per day) was higher among homosexual and bisexual men $(8.3 \%)$ than among heterosexual men $(2.5 \%)$, and it was highest among HIV-seropositive men $(9.4 \%)$.

In a 1991 San Francisco convenience sample survey of alcohol and other drug use among 416 gay and bisexual men (mean age: 35 years; age range : $18-76$ years $; 79 \%$ white; $88 \%$ with ations in immune function and inflammatory response among cigarette smokers, including elevated leukocyte counts, alterations in Tlymphocyte subsets, and changes in immunoglobulin levels. ${ }^{7}$ Normal T-cell function plays an essential part in the defence against the development of both infection and neoplasia. Analysis of T-lymphocyte subsets in smokers have generally shown increases in total $\mathrm{T}$-cell and CD4 + (T-helper) cell counts in light and moderate smokers, but a relative decrease in the $\mathrm{CD} 4+$ subset and an increase in the $\mathrm{CD} 8+$ (T-suppressor) subset in heavy smokers, though these changes are generally reversible with smoking cessation. ${ }^{7}$ In addition, smokers have a significantly lower proportion of circulating natural killer cells, a decrease that persists despite smoking cessation. ${ }^{8}$

Cigarette smoking's effects on CD4 + cells 
have been recently studied in both healthy and HIV-infected individuals. Smoking increases CD 4 + cell counts in healthy whites, ${ }^{9}$ though the reverse may be true in blacks. ${ }^{10} \mathrm{CD} 4+$ cell counts have been noted to fall in smokers who quit and to increase in non-smokers who begin smoking. ${ }^{4}$ Higher CD $4+$ cell counts have also been observed among smokers, compared with non-smokers, in studies of men with recent HIV infection; but these counts initially fall faster in smokers, and the difference between the counts for smokers and non-smokers is markedly reduced within 2 years after seroconversion..$^{3,411}$ Such effects may require clinicians and researchers who measure $\mathrm{CD} 4+\mathrm{T}$ lymphocyte counts in HIV-infected individuals to consider smoking status when interpreting CD $4+$ cell levels in recently infected persons.

Smoking and the course of HIV disease Despite their initially higher CD4 + T-lymphocyte counts, smokers with HIV infection do not fare better than non-smokers, and they may do worse. Two recent prospective studies have examined the effect of smoking status on homosexual men with known or estimated dates of HIV seroconversion. In a study of male sexual contacts of men with AIDS, smoking status at enrollment was not associated with the contacts' later progression to AIDS. ${ }^{12}$ The subjects were not stratified by amount of cigarette consumption, however, so an effect limited to heavy smokers might not have been detected. In a more detailed analysis, Burns $^{3}$ similarly reported that smoking was not associated with a subsequent increased risk of either Pneumocystis carinii pneumonia (PCP) or other AIDS-defining conditions. A number of these subjects reduced or discontinued their smoking during the study, however, and the study may not have had enough power to control for this and identify a meaningful dose effect.

In two other analyses, smoking was associated with an increased risk of $\mathrm{AIDS}^{13}$ or PCP. ${ }^{14}$ These studies controlled for CD4 $+\mathrm{T}$ lymphocyte cell counts rather than time of seroconversion, and the findings might have resulted from higher CD4+ cell counts in smokers at seroconversion rather than faster progression to AIDS. In a third analysis, researchers found no association after adjusting for duration of HIV infection. ${ }^{15}$

\section{Conclusions}

In summary, homosexual men do appear to have a higher prevalence of smoking than do men in the general population, though no firm conclusions can be drawn about the association between smoking and HIV-associated morbidity. What is certain, however, is that smoking is associated with many other diseases and that it adversely affects many organ systems, including the immune system. ${ }^{16,17}$ Clearly, any increase in smoking would be expected to be harmful to the gay population.

As early as 1985 , Newell ${ }^{18}$ called for smoking cessation as a possible means of reducing the risk of homosexual men acquiring AIDS. While it is not clear that smoking increases the risk of acquiring HIV infection, given the high smoking prevalence among gay men, smoking cessation efforts targeted to this population are certainly needed for a variety of health reasons. With AIDS ravaging gay communities in the US, niche marketing of tobacco products to gays only adds further insult to a population already at risk.

Addendum: As this issue of Tobacco Control was going to press, a study on the relationship between cigarette smoking and the progression of AIDS was published (Nieman RB, et al. The effect of cigarette smoking on the development of AIDS in HIV-1-seropositive individuals. AIDS $1993 ; 7: 705-10)$. The study population included 84 individuals with AIDS seen at the genitourinary medicine outpatient department of St Mary's Hospital in London, UK, who provided information on their smoking behaviour before their AIDS-defining diagnosis.

The authors reported the following findings: "Progression time to AIDS (all diagnoses) was significantly reduced in $H I V-1$-seropositive smokers: median time to AIDS was 8.17 months for smokers $(n=43)$ and 14.50 months for nonsmokers $(n=41) \quad(\mathrm{p}=0.003)$. Smokers developed Pneumocystis carinii pneumonia (PCP) more rapidly than non-smokers, with a median time to PCP of 9.0 months, compared with 16.0 months for non-smokers $(\mathrm{p}=0.002)$. Smoking had no significant effect on progression time to AIDS when not due to PCP."- ED

1 Lipman J. Philip Morris to push brand in gay media. Wall Street fournal, August 13, 1992, B1

2 National Center for Health Statistics. Health, United States, 1991. Hyattsville, Maryland: Public Health Service, 1992. (DHHS publication (PHS) 92-1232.)

3 Burns DN, Kramer A, Yellin F, Fuchs D, Wachter H, DiGioia RA et al. Cigarette smoking: a modifier of Human Immunodeficiency Virus Type 1 Infection? $f$ Acquir Immune Defic Syndr 1991; 4: 76-83.

4 Royce RA, Winkelstein W. HIV infection, cigarette smoking and $\mathrm{CD} 4+\mathrm{T}$-lymphocyte counts: preliminary results from the San Francisco Men's Health Study. AIDS $1990 ; 4: 327-33$.

5 Burns D, Pierce JP. Tobacco Use in California 1990-1991. Sacramento, California: California State Department of Health Services, 1992: 2A

6 Halsey NA, Coverly JS, Holt E, Coreil J, Kissinger P, Moulton LH et al. Sexual behavior, smoking and HIV-1 infection in Haitian Women. $\mathcal{F} A M A$ 1992; 267: 2062-6.

7 Holt, PG. Immune and inflammatory function in cigarette smokers. Thorax 1987; 42: 241-9.

8 Tollerud DJ, Clark JW, Brown LM, Neuland CY, Mann DL, Pankiw-Trost LK et al. Association of cigarette smoking with decreased numbers of circulating natural killer cells. Am Rev Respir Dis 1989; 139: 194-8.

9 Tollerud DJ, Clark JW, Brown LM, Neuland CY, Mann DL, Pankiw-Trost LK et al. The effects of cigarette smoking on $\mathrm{T}$-cell subsets; a population based survey of healthy Caucasians. Am Rev Respir Dis 1989; 139: healthy $1446-51$.

10 Tollerud DJ, Brown LM, Blatterner WA, Mann DL, Pankiw-Trost L, Hoover RN. T cell subsets in healthy black smokers and non-smokers. Am Rev Respir Dis 1991 ; 144(3): 612-6.

11 Park LP, Muñoz A, Armenian H, Margolick J, Giorgi JV, Ferbas J et al. Interaction between HIV-1 infection and smoking on CD4 lymphocyte count [Abstract Th.C.675]. Sixth International Conference on AIDS, Final Program and Abstracts, Vol 1. San Francisco, California: University of California, San Francisco, 1990.

12 Coates RA, Farewell VT, Raboud J, Read SE, MacFadden DK, Calzavara LM et al. Cofactors of progression to acquired immunodeficiency syndrome in a cohort of male sexual contacts of men with human immunodeficien
virus disease. Am $\mathcal{F}$ Epidemiol 1990; 132: 717-22.

13 Royce RA, Winkelstein W, Bacchetti P. Cigarette smoking and incidence of AIDS [Abstract TH.C.39]. Sixth 
International Conference on AIDS, Final Program and Abstracts, Vol 1. San Francisco, California: University of California, San Francisco, 1990.

14 Buskin SE, Hopkins SG, Farizo KM. Heavy smoking increases the risks of Pneumocystis carinii pneumonia (PCP) [Abstract WeC 1030]. Final Program and Oral Abstracts, VIII International Conference on AIDS, III STD World Congress, 19-24 fuly 1992. Amsterdam, The Netherlands: Harvard University, 1992 .

15 Craib KJ, Schechter MT, Montaner JS, Le TN, Sestak P, Willoughby $\mathrm{B}$ et al. The effect of cigarette smoking on ymphocyte subsets and progression to AIDS in a cohort of homosexual men. Clin Invest Med 1992; 15: 301-8.
16 US Department of Health and Human Services. Reducing the health consequence of smoking : 25 years of progress. $A$ Report of the Surgeon General. Rockville, Maryland: US Department of Health and Human Services, 1989. (DHSS publication (CDC) 89-8411.)

17 Centers for Disease Control. The health benefits of smoking cessation: a report of the Surgeon General, 1990 . Rockville, Maryland:US Department of Health and Human Maryland:US Department of Health and Human 18 Newell GR, Mansell PWA, Wilson MB, Lynch HK, Spitz MR, Hersh EM. Risk factor analysis among men referred for possible acquired immune deficiency syndrome. Prev Med 1985; 14: 81-91.
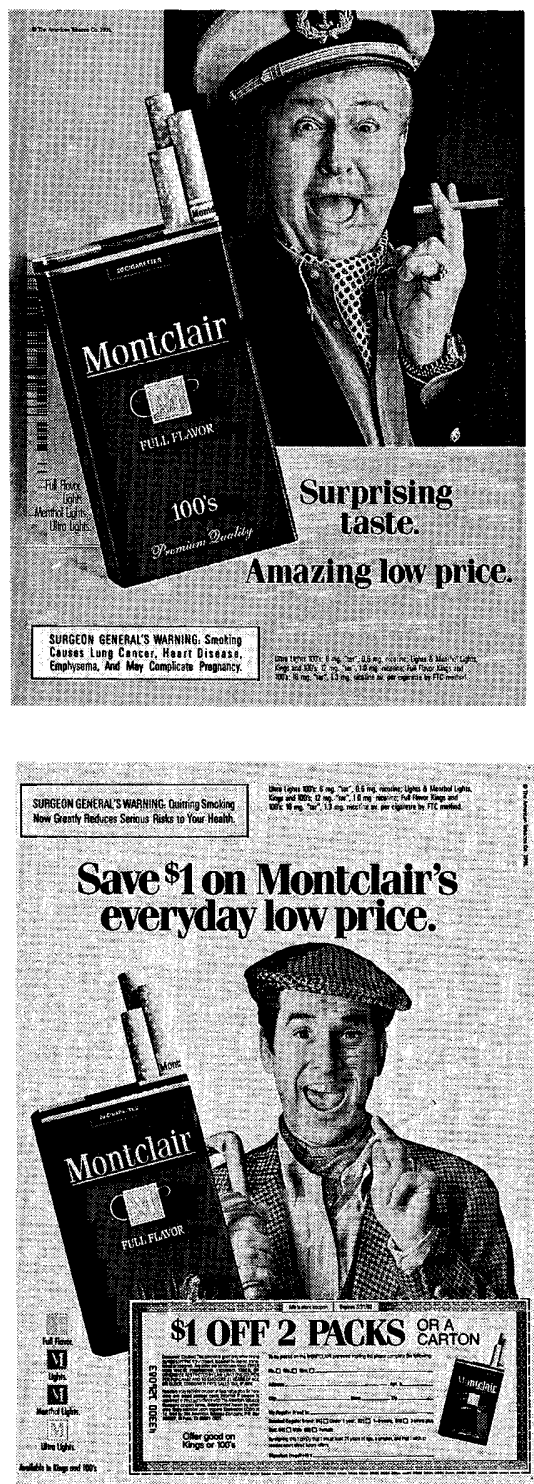
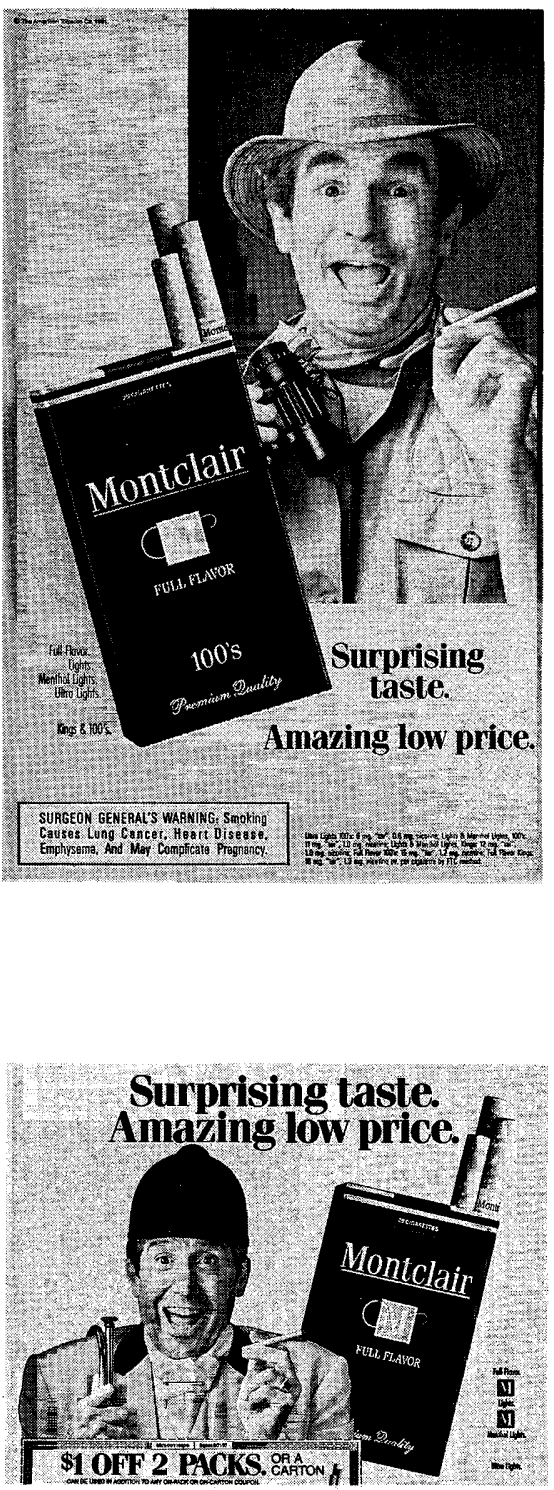

An article in the 7 fuly 1991 issue of the Detroit News suggested that the advertisement shown on the top left may have been directed toward gay men. The article described the ad as follows: "... a mug shot of what looked to many like an aging, effeminate homosexual-captain's cap on head, pinky ring (no marriage ring), dapper ascot-shrieking in pleasure over his cigarette".

This ad was part of a series of ads, three others of which are shown here, produced by Lawrence Charles Free \& Lawson (New York City) for American Brands. Roger Baker, a spokesman for American Brands, told the Detroit News that the ad described in the article was not intended to portray a gay man. According to Baker, "The model portrays an upscale, wealthy gentleman who has been pleasantly surprised by the cigarette". - ED 